\title{
Earnings Persistence and Firm Performance: Implications of Analysts' Accurate Forecast Ability from the Emerging Market of Nigeria
}

\author{
Anaekenwa Theophilus Aguguom ${ }^{1 *}$, Samuel O Dada ${ }^{2}$, Appolos N Nwaobia ${ }^{2}$ \\ ${ }^{1}$ Accounting and Finance Department, Augustine University, Ilara-Epe, Lagos State, Nigeria; ${ }^{2}$ Accounting Department, Babcock University, \\ Ilishan Remo, Ogun State, Nigeria
}

\begin{abstract}
This paper empirically examined the potency and value relevance of earnings persistence (EPERS) and its effect on firm performance and the implications of the analysts' accurate forecast ability from the emerging market of Nigeria. The study adopted the expo facto research design and sampled 51 companies listed on the Nigerian Stock Exchange using stratified random sampling techniques from all the sectors from the 2000-2016 periods. Descriptive and Panel data regression statistics were employed in the analysis of the effect of earnings persistence on firm performance. Pre and post estimation tests were carried out: variance inflation factor (VIF) showed no evidence of multicollinearity among the variables, correlation matrix test did not revealed any multi-collinearity problem, normality test using Jarque-Bera test of normality posed no problem to the study. While Breusch-Pagan/Cook-Wesberg tests to assess the variance in the error terms (residuals) of the models, the results indicated that all the models did not suffer from heteroskedasticity. Notwithstanding, panel robust standard error (PRSR) was employed to control the heteroscedasticity. The study revealed that earnings persistence (EPERS) had a negative and no significant effect on firm performance (Tobin's Q). Leverage (LEV) exhibited a positive relationship whereas firm size (FRMSIZE) revealed a negative relationship with Tobin's Q (TQ). Also based on findings, a weak growth trend was established between EPERS and Tobin's Q. Earnings persistence resulting from discretionary and opportunistic earnings could give inaccurate forecasting ability. Consequently, the study recommended that analysts should be watchful of the stable occurrence of earnings when evaluating reported financial statements, without which, predictions made from them could have negative and misleading implications.
\end{abstract}

Keywords: Earning persistence; Forecast ability; Firm performance; Economic value added

\section{INTRODUCTION}

The integrity of the reported earnings now seems questionable, despite the adoption of International Financial Reporting Standards (IFRS). One of the desires of financial analysts is to see that firms' earnings are consistent in order to evaluate accurately, the degree to which earnings reflect the underlying fundamentals of the firm performance over the years and not just one-off performance [1]. Confidence in reported earnings are fast eroding away because investors and the analysts now believe there are possibilities of opportunistic earnings and biased reporting by the management to cover up incompetence, inefficiency and apprehension in meeting the expectations of the investors and other stakeholders [2]. Managers play all tricks, both at the level of form or content, to respond to market expectations and requirements [3] since managers are free to select accounting and reporting methods in the preparation of financial reports [4]. Naturally, earnings are regarded to be of high quality when they are persistent and not a product of earnings management, hence deemed desirable by analysts and investors for investment decisions, because when earnings are persistence, they can be used as a predictor for the future performance of a company while analysts appreciate them as a good predictive tool for investment forecast [5,6].

Earnings persistence is associated with an inclusive performance of a firm as portrayed in her corporate goal attainment, profits sustained over periods of time and non-earnings opportunistic practices involvement. Naturally, earnings persistence is the timeseries parameter that measures the magnitude of the effect of permanent earnings innovation on expected future earnings [7]. Investors largely depend on the advisory role of analysts in the face of risk and uncertainties associated with investments and portfolio diversifications, since financial reports is a reflection

*Correspondence to: Anaekenwa Theophilus Aguguom, Accounting and Finance Department, Augustine University, Ilara-Epe, Lagos State, Nigeria, Tel: 08122221167; E-mail: theophilus.aguguom@augustineuniversity.edu.ng

Received: March 15, 2019; Accepted: April 10, 2019; Published: April 17, 2019

Citation: Aguguom AT, Dada SO, Nwaobia AN (2019) Earnings Persistence and Firm Performance: Implications of Analysts' Accurate Forecast Ability from the Emerging Market of Nigeria. Int J Account Res 7:197. doi: 10.35248/2472-114X.19.7.197

Copyright: (C) 2019 Aguguom AT, et al. This is an open-access article distributed under the terms of the Creative Commons Attribution License, which permits unrestricted use, distribution, and reproduction in any medium, provided the original author and source are credited. 
of financial performance and a general measure of a company's financial health over a period of time [5]. Investors and financial analysts, desire that the financial reports are the true underlying reality of operational and financial performance; that the market share prices being reported are a true reflection of the management competencies and in maximizing investors' portfolios, so as not to mislead unsuspected investors as confirmed in the previous studies $[8,9]$, since reported profit as a reflection of true firm performance to aid investors economic decisions [10].

Against this backdrop, and in extending prior related literature in earning persistence, the objective of this paper is to examine empirically the effect and implication of earnings persistence on firm performance, and analysts accurate forecast ability in evaluating and predicting future earnings of firms and advising investors in making informed and non-misleading investment decisions from the listed companies in Nigeria, using descriptive and inferential analyses to examine the trend of earnings persistence of 51 listed companies from the Nigerian Stock Exchange towards expanding the emerging market frontier in accounting.

\section{LITERATURE AND HYPOTHESIS DEVELOPMENT}

\section{Earnings persistence}

The study of Schipper and Vincent [11] defined earnings persistence as a measure of earnings quality revealing the sustainability of earnings. Other studies estimate earnings persistence as a regression of the future value as one of the variables of earnings quality on its current value $[12,13]$. The concept of earnings persistence shows the reoccurrence of earnings. Similarly, the study of Prapaporn [14] opined that earnings with low earnings persistence may not be an appropriate performance measure for chief executives officers (CEOs) because earnings may not signal their efforts in general terms.

Earnings quality is seen as only useful if it precisely reveals the reality of the company, suggesting that financial statements show an accurate and unbiased state of the company, giving a precise, timely, and transparent, persistent and comparable financial information [15]. However, the study of Dechow et al. [16] elucidated more on the logic behind earnings persistence: That if company Y market share price shows more persistence earnings than company $\mathrm{X}$ in perpetuity, then company $\mathrm{Y}$ earnings are a more useful synthetic measure of future performance and annualizing its current earnings will result in fewer estimation error.

\section{Firm performance}

Firm performance could be referred to as the degree to which a company's overall objectives including profitability sustaining and financial goals have been achieved [17]. It could also include the ability to measure the results of a company's policies and set operations in monetary terms. Firm performance, ideally, measures the general financial and economic health condition of a company over a given period of time, and could as well be used to compare similar companies within and across the same industry or sector. Further argued that profitability is the most common measure of a company's financial performance, apart from meetings its target obligations. Profitability studies classify measures and assess the performance of the firm in terms of the profits it earns with regards to the shareholders' investment or capital employed in the business.
Most investors only invest in the returns and the profit that the investment yields, therefore profitability could be used as a measure of the success of an investment. Furthermore, profitability is the business's ability to create earnings in relation to its expenses and other related costs of the business incurred during the relevant period. Therefore, the ability of a company to continue to operate and be in business largely depends on its ability to generate profit and continue to exist. Hifza [18] stated that profitability is one of the important aims of financial management since the prime aim of the financial investment is to maximize the owners' wealth and profitability is very germane as a determinant of business investment success and financial performance. The market share price of companies depends fundamentally on the ability of the company to make a profit on a continuous basis and ensure that the going concern principle is not being threatened [19].

\section{Theoretical framework}

Clark's theory of profitability emphasizes economic analysis of profit and its clear future considerations. According to Clark's theory of profitability, the underlying assumptions of any economy without profit intentions are termed as that of perfect market conditions, static state, constant factors of production, absence of monopoly not predisposed to change and the market is assumed to be perfect; hence the absence of monopoly and entrepreneurial efforts are rewarded according to management wage levels. Siddiqi [20] stated that in such an economy, the society acts and lives but does so in a changeless manner.

Therefore, Clark's theory highlights that economies driven by profits will not suffer from sudden collapse. It is this frictional delay that the investor takes advantage of and makes transactional profits before equilibrium returns and consumers expected profits. Siddiqi [20] further argued that profit is a transitional occurrence as its temporary nature demands from the investor a dynamic endeavor to seek out or generate opportunity on which to capitalize even as economies are dynamic. Clark's profitability theory further explains that five outlined variables are never static: population and capital are in constant growth, innovation in production and management of resources are intermittently researched and consumers' demands do vary often and subject to changes in taste, style and trends effect. The investors, as a result, find permanence for as long as there are changes, react before competitors and organizes efforts with sound information of market changes.

Free cash flow theory is framed for matured firms that are likely to over-invest. It says that high debt levels will increase value, regardless of the threat of financial distress, especially, when a company's operating cash flow significantly exceeds its profitable investment opportunities [21]. The profit earning capacity grows the value of the company despite the threat of financial distress. Firms with a negative free cash flow increase their debt ratio to respond to the lack of internal funds. Therefore, the percentage adjustment is small for firms with relatively more debt than for firms with relatively low debt.

\section{Empirical review}

Earnings persistence and firm performance: Myers et al. [21] examined the effect of firm performance through profitability on firm value. The study employed secondary data obtained from manufacturing companies listed on the floor of the Indonesia Stock Exchange for a period of 6 years 2009-2014. The study found 
that profitability as a measure of firm performance using Tobin's $Q$ has a positive effect on firm value. The study further found that dividend payment as a sign of profitability increases the firm share price.

From Iran, Sabrin et al. [22] examined the effect of firm size and financial leverage on the relationship between cost management and the relevance of accounting information on the companies listed on the Tehran Stock Exchange [23]. The study used 101 companies for a period of 10 years (2004-2013) with Ohlson's pattern in which the relevance of earnings per share and book value per share were examined using market value per share. The study found that cost management significantly and positively affects share value. The study also found that financial leverage doesn't have a significant impact on firm value.

From the Philippines, Sucuahi and Cambarihan [24] study on the measuring ability of Tobin's Q, examined the impact of profitability on the firm value of diversified companies in the Philippines. The main objective of the study was to determine if there is a significant relationship between the company's profile such as industry, company age, and its profitability with the firm value using Tobin's $Q$ model. The study employed 86 diversified companies listed in the Philippines Stock Exchange. The result from the study revealed that, of the three factors assumed to influence the value of the firm using Tobin's model, only profitability shows a significant positive impact on the firm's value. The study concluded that Tobin's $Q$ is considered as one of the best predictors of a market situation and it can also explain the majority of the investment variability.

\section{METHODOLOGY}

\section{Research design}

This study adopted stratified random sampling techniques in selecting 51 companies out of 173 listed firms on the Nigerian Stock Exchange (NSE) from 2000-2016. The adequacy of the information content of the published financial statements was a determining factor in the final selection of a company as a unit of the study, as any company with insignificant information and/ or missing data relevant to the study was dropped. Data were extracted from published financial statements of the sampled firms for the period under consideration. Descriptive and Panel data analyses were used to examine the trend of earnings persistence and firm performance and also the impact of earnings persistence on firm performance with the identified variables and specified data regression models using unobserved effects model (UEM). The UEM can either be fixed effect or random Effect depending on the assumption about the distribution of the unobserved components and the error term, and the stochastic process of the time series across $i$, as well as the asymptotic properties of $t$ and $i$ with $p$-value $>0$, the result of the Hausman test indicated between fixed effect and model and random effect model, implying that any of the models could be used.

\section{Pre-estimation tests}

Correlation matrix: Correlation matrix was used to determine whether there are bivariate relationship between each pair of the dependent and independent variables considered in this study and to ensure that the correlations among the explanatory variables are not so high to the extent of posing multi-collinearity problems no evidence of multi-collinearity among the variables. EPERS is positively and insignificantly correlated with TQ $(\mathrm{r}=0.079)$. The correlations between LEV and TQ were significant at 5\% level of significance. All the correlation coefficients between EPERS, LEV, FRMSIZE, and TQ $(\mathrm{r}=0.079,0.227$ and 0.015$)$ indicate insignificant but positive association (Table 1).

Variance inflation factor: Variance inflation factor (VIF) test was carried out for robustness, the variables considered in this study is subjected to multi-collinearity test using variance inflation factor (VIF). These indicate that the variables under consideration are not perfect linear combination of each other and harmful effect of multi-collinearity and the result is presented in Table 2. Numerous authors emphasized that a VIF that is above 10 and a tolerance value that is approaching 1 indicate no harmful effect of multicollinearity. Judging from the result, the average VIF values are 1.05 (for model without firms' characteristics) and 1.08 (model without firms' characteristics) which are far less than 10. Specifically, EPERS have VIF values of 1.01 in panel A while, EPERS, LEV and FRMSIZE have VIF values of 1.02, 1.05, 1.12, respectively in Panel B. Also, the corresponding reciprocal of tolerance are close to 1 .

\section{Measurement of variables}

\section{Dependent variable}

Firm performance: In this paper, firm performance is measured with Tobin's Q. Tobin's $Q$ as a measure of firm performance variable, from the perspective of investment has been tested in various situations [25]. This study adopted this variable in line with prior studies: Firm valuation [26-28]. In this study, because of the difficulty in estimating the market value of debt and replacement costs, the study adopted [26] model and follows common practice and compute Tobin's Q as:

$T Q_{i t}=\frac{\left(\mathrm{BVA}_{\mathrm{it}}+\mathrm{MVE}_{\mathrm{it}}-\mathrm{BVE}_{\mathrm{it}}\right)}{\mathrm{BVA}_{\mathrm{it}}}$

where,

$T Q_{i t}=$ The Tobin's $\mathrm{Q}$ value of firm $i$ in year $t$,

$B V A_{i t}=$ The book value of total assets of firm $i$ in year $t$,

$M V E_{i t}=$ The market value of common equity of firm $i$ (computed

Table 1: Correlation matrix.

\begin{tabular}{|ccccc} 
& TQ & EPERS & LEV & FRMSIZE \\
\hline TQ & 1 & 0.079 & $0.227^{*}$ & 0.015 \\
\hline EPERS & & 1 & 0.048 & -0.036 \\
\hline LEV & & & 1 & 0.035 \\
\hline FRMSIZE & & & & 1 \\
\hline
\end{tabular}

*p-value $<0.05$

Table 2: Variance inflation factor. Source: Author's computation, underlying data from annual reports of firms listed on NSE. The earnings persistency indicators are computed using a 5-year rolling window.

\begin{tabular}{lcccc}
\hline Variable & \multicolumn{2}{c}{$\begin{array}{c}\text { Model without firms' } \\
\text { characteristics (Panel A) }\end{array}$} & \multicolumn{2}{c}{$\begin{array}{c}\text { Model with firms' } \\
\text { characteristics (Panel B) }\end{array}$} \\
\cline { 2 - 5 } & VIF & 1/VIF & VIF & 1/VIF \\
\hline EPERS & 1.01 & 0.988 & 1.02 & 0.98 \\
\hline LEV & & & 1.05 & 0.949 \\
\hline FRMSIZE & & & 1.12 & 0.896 \\
\hline Mean VIF & 1.05 & & 1.06 & \\
\hline
\end{tabular}

EPERS: Earning persistence; LEV: Leverage and FRMSIZE: Firm Size 
as stock price $\times$ the number of common shares outstanding in year $t$, and

$B V E_{i t}=$ The book value of equity (total shareholders' fund) of firm $i$ in year $t$

\section{Independent variables}

Earnings Persistence: To measure the persistence of any variable, the estimate of regression of the future value of the variables on its current value is carried out as in Dechow and Schrand [12].

$N I B E X T_{i t}=\phi_{0 i}+\phi_{i t} N I B E X T_{i t-1}+\mu_{i t}$

where,

$N_{I B E X T_{i t}}=$ Net income before extraordinary items of companies $i$ in year $t$,

$N_{I B E X T_{i t-1}}=$ Net income before extraordinary earnings items of company $\mathrm{i}$ in year $\mathrm{t}-1$,

$\phi_{o i}=$ CONSTANT (intercept) coefficient,

$\phi_{1 i}=$ THE non-constant (slope) coefficient, and

$U_{1 i}=$ The residual (error term).

\section{Control variables}

Leverage: Leverage is widely used as a controlling variable in earnings persistence as one of the proxies of earnings quality and earnings management [29]. In this study, leverage is taken to be the debt-to-assets ratio of each of the firms as used in the study of Hamidzadeh and Zeinali [30]. It is computed as total liabilities divided by total assets $\times 100 \%$,

LEV $=\frac{\text { Total Liabilities }}{\text { Total Assets }} \times 100$

Firm size: Firm size has been identified as important determinant of firm valuation [26]. While Singh and Davidson, Hribar and Nichols [31,32] argued that firm size has the capacity to capture business diversification in larger firms such that asset utilization and association with total accruals might differ due to economies of scale. Earlier research works have found indication that firm valuation is positively related to growth opportunities. The firm size in this study, consistent with Gaio and Raposo [26], is measured as the log of total assets in the thousands of Naira of firm $i$ for time period $t$.

\section{FRMSIZE $=$ Log Total Assets}

Research question: How does earnings persistence impact firm performance and control variables of firm size and leverage of quoted companies in Nigeria?

Research hypothesis, $\mathrm{H}_{01}$ : Earnings persistence does not have any significant impact on firm performance and the control variables of firm size and leverage of quoted companies in Nigeria.

\section{Operationalization of variables and model specification}

$\mathrm{Y}=f(\mathrm{XZ})$

$\mathrm{Y}=$ Firm performance

$\mathrm{X}=$ Earnings persistence

$\mathrm{Z}=$ Control variable

$\mathrm{Y}=\mathrm{y}_{1}$

$\mathrm{X}=\mathrm{x}_{1}$,
$\mathrm{Z}=\mathrm{z}_{1}, \mathrm{z}_{2}$

Sub-variables of $\mathrm{Y}, \mathrm{X}$ and $\mathrm{Z}$

$\mathrm{y}_{1}=$ Tobin's (TQ)

$\mathrm{x}_{1}=$ Earnings persistence (EPERS)

$z_{1}=$ Firm size (FRMSIZE)

$z_{2}=$ Leverage $(\mathrm{LEV})$

\section{Functional relationship}

$T Q=(E P E R S, F I R M S I Z E, L E V)$

$Y_{i t}=\beta_{0}+\beta_{1} X_{i t}+\beta_{2} Z_{i t}+\mu_{i t}$

$T Q_{i t}=\beta_{0}+\beta_{1}$ EPERS $_{i t}+\beta_{2}$ FRMSIZE $_{i t}+\beta_{3} L E V_{i t+} \mu_{i t}$

where,

$Y=$ Dependent variable; $X=I n d e p e n d e n t$ variable; $Z=$ Control variables; $T Q=$ Tobins's $Q ; E P E R S=$ Earnings persistence; FRMSIZE=Firm size and $L E V=$ Leverage

$\beta_{0}=$ the regressions intercept which is constant

$\beta-\beta_{3}$, =the coefficient of the explanatory variable

$\mathcal{\varepsilon}=$ the error term of the model

$i=$ cross-sectional variable

$t=$ time series variable

\section{Models}

Pool regression model: The starting model is the pooled regression model where it is assumed that any heterogeneity across firms has been averaged out. The pooled estimation model is given as:

$T Q_{i t}=\beta_{0}+\beta_{1} E P E R S_{i t}+\beta_{2} F R M S I Z E_{i t}+\beta_{3} L E V_{i t}+\mu_{i t}$

Random effect model: The random effect model assumes that the individual heterogeneity is uncorrelated with (or, strongly, statistically independent of) all the observed variables. Going by this assumption the following models are specified:

$T Q_{i t}=\beta_{0}+\beta_{1} E P E R S_{i t}+\beta_{2} F R M S I Z E_{i t}+\beta_{3} L E V_{i t}+V_{i t}$

Fixed panel regression model: The fixed effect model assumes that individual heterogeneity is captured by the intercept term. This means every individual is assigned its intercept while the slope coefficients are the same, and the heterogeneity is associated with the regressors on the right hand side. In the model also we introduced dummy.

$$
T Q_{i t}=\beta_{0}+\beta_{1} \text { EPERS }_{i t}+\beta_{2} \text { FRMSIZE }_{i t}+\beta_{3} L E V_{i t}+{ }_{i t} \sum_{(i=1)}^{(n-1)} D_{i}+\mu_{i t}
$$

\section{A priori expectation}

These are the expectations that there exist relationship of the variables- dependent and independent variables. This refers to how earnings persistence relates to firm performance. Accordingly, there is an assumption that earnings persistence will be statistically and significantly influence Tobin's as a proxy of firm performance, this would promote healthy and the needed confidence among the various investors. However, the level and magnitude of the influence is yet to be established. Consequently, the study's a priori expectation is represented thus $\beta_{1} \beta_{2}, \beta_{3}>0$ and all the coefficients should be positively signed. 


\section{DATA ANALYSIS, RESULTS AND DISCUSSIONS}

\section{Trend analysis}

Firm performance (Tobin's Q) in Figure 1A reveals a growth of approximately $3 \%$ for the period up to 2015 . However, earnings persistence grew by $33 \%$ between the periods. It further suggests that firm performance and earnings persistence moved in the same direction suggesting that firm performance reacted as the earnings reduces within the period under consideration.

\section{Regression}

Tobin's $Q=7.243-0.001 E P E R S+0.802 L E V-0.763$ FRMSIZE

Based on the Hausman-statistics $(66.76 ; p=0.000)$, the null hypothesis that the individual-level effects are adequately modeled by a random-effects model is rejected. Hence, the fixed effect (FE) model is chosen as the lead model for interpretation. From the model, the estimated coefficients indicate that earnings persistence (EPERS) and firm size (FRMSIZE are all negatively signed $(\beta 1=-0.001 ; \beta 2=-0.763)<0)$. These are not in consonance with expectations. However, leverage (LEV) is positively signed in line with a priori expectation $\beta 3=0.802>0$.

Based on the coefficient of the variables, the result further reveals that an increase in the level of leverage will lead to an increase of 0.802 on firm performance (Tobin's Q). The Breusch and Pagan Lagrangian multiplier test for random effects figure which is 799.07 $(p=0.000)$ strongly suggest the rejection of the null hypothesis of "no panel effect", therefore accepts the alternative hypothesis and concludes that panel is appropriate. The result, therefore, shows that the F-statistics value of $(11.000 ; p=0.000)$ associated with the lead model indicates the significance of the model at a $1 \%$ level of significance. In order word, it implies that all the independent variable and the control variables are jointly and statistically significant in affecting TQ. The $\mathrm{R}^{2}=0.186$ indicates that $18.6 \%$ of variations in $T Q$ are accounted for by the independent variables (Table 3).

The evidence of a negative and significant relationship between leverage (LEV) and earnings persistence (EPERS) is recorded in

Tobin's Q and Earnings Persistence

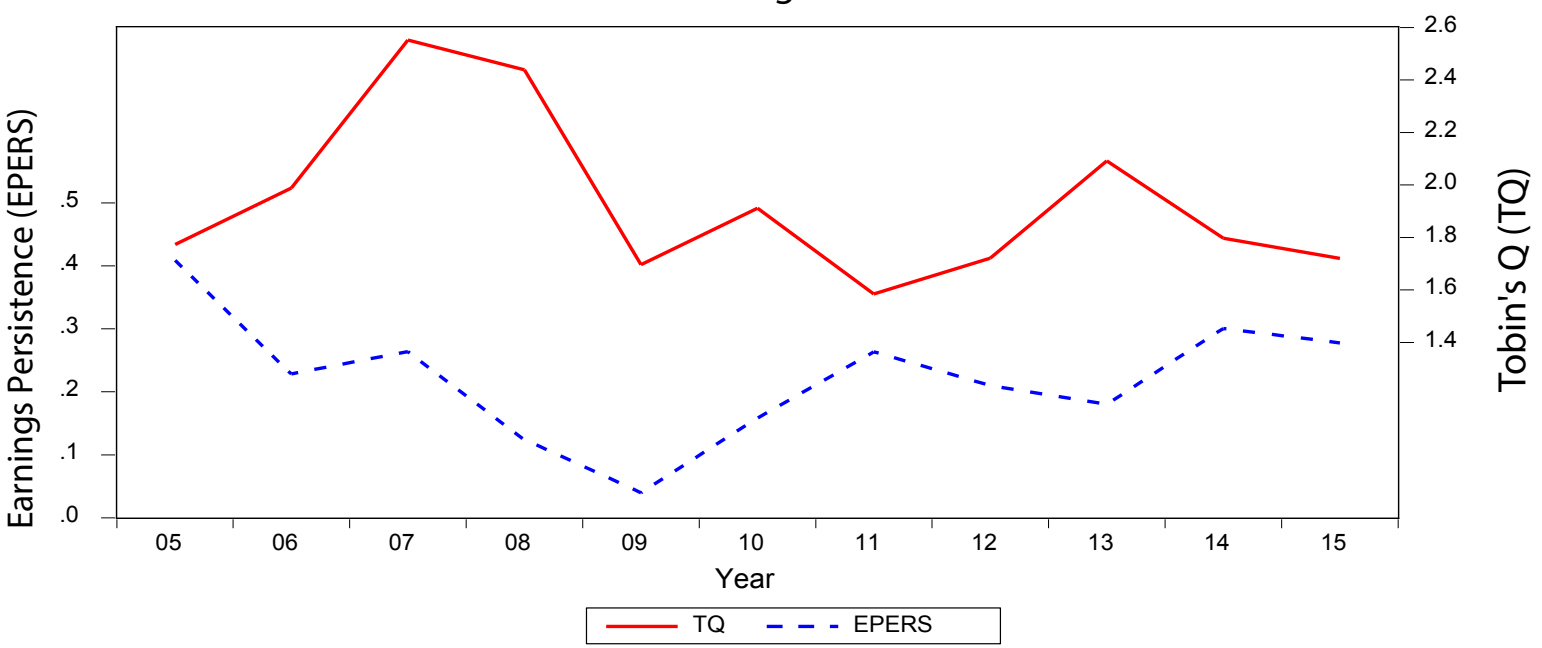

Figure 1A: Trend analysis, earnings persistence and firm performance. Source: Authors' computation, 2018.

Table 3: Earnings persistence, Lev, and Firm size indicators and firm performance (Tobin's Q). Source: Author's computation, underlying data from annual reports of firms listed on NSE. The earnings persistence indicators are computed using a 5-year rolling window.

\begin{tabular}{|c|c|c|c|c|c|c|c|c|c|}
\hline \multirow[t]{3}{*}{ Variables } & \multicolumn{3}{|c|}{-1} & \multicolumn{3}{|c|}{-2} & \multicolumn{3}{|c|}{-3} \\
\hline & \multicolumn{3}{|c|}{ OLS } & \multicolumn{3}{|c|}{$\mathrm{RE}$} & \multicolumn{3}{|c|}{$\mathrm{FE}$} \\
\hline & Coeff. & t-stat & $p$-value & Coeff. & t-stat & $p$-value & Coeff. & t-stat & $p$-value \\
\hline EPERS & $0.120^{*}$ & 1.73 & 0.085 & 0.012 & 0.24 & 0.812 & -0.001 & -0.02 & 0.987 \\
\hline LEV & $0.656^{* * *}$ & 4.03 & 0 & $0.874^{* * *}$ & 5.12 & 0 & $0.802^{* * *}$ & 3.67 & 0.001 \\
\hline FRMSIZE & 0.046 & 0.71 & 0.476 & $-0.403^{* * *}$ & -2.71 & 0.007 & $-0.763^{* * *}$ & -3.44 & 0.001 \\
\hline Constant & $1.232^{* *}$ & 2.18 & 0.03 & $4.588^{* * *}$ & 4.13 & 0 & $7.243^{* * *}$ & 4.41 & 0 \\
\hline Observations & & 561 & & & 561 & & & 561 & \\
\hline R-squared & & 0.108 & & & 0.177 & & & 0.186 & \\
\hline Adj. R-squared & & 0.096 & & & 0.166 & & & 0.175 & \\
\hline Firm effect & & No & & & Yes & & & Yes & \\
\hline Year effect & & No & & & No & & & No & \\
\hline F-test & & 8.03 & & & 74.97 & & & 11 & \\
\hline Prob $>F$ & & 0 & & & 0 & & & 0 & \\
\hline LM Test (Prob) & & & & 799.07 (0. & & & & & \\
\hline Hausman (Prob) & & & & 66.76 & & & & & \\
\hline
\end{tabular}

The dependent variable is the earnings persistence-Tobin's $Q\left(T Q:{ }^{* * *} p\right.$-value $<0.01,{ }^{* *} p$-value $<0.05,{ }^{*} p$-value $\left.<0.1\right)$

EPERS: Earning persistence; LEV: Leverage; FRMSIZE: Firm Size 
this study. It corroborated previous conclusions in the literature, notably the study of Ali et al. [33]. They found an inverse association between leverage (LEV) and earnings persistence and share price (SP) of listed manufacturing firms in Nigeria. The study also revealed that a positive association exists between firm size and book value; this also aligns with Robert and Jane [34]. In like fashion for Frank and Goyal [35] and Acheampong et al. [36], there is further evidence that leverage has a positive relationship with Tobin's $Q$ while firm size has a negative relationship with the performance indicator. The result equally revealed a negative effect of leverage on market share price of the companies.

Also on leverage, the study found a positive and significant relationship between leverage and firm performance (TQ). This is consistent with the findings and studies of that found that leverage is positively related to firm value, and also that value of a leveraged firm will be greater than the value of a similar unleveraged firm [37-39]. Also, some studies confirm a positive effect of leverage on firm value especially when inflation is higher [35,40,41]. However, in contrary findings, and contributing to this argument, find a negative influence of leverage on the firm value which tends to be strong if free cash flow is higher [42-44]. This could be due to debt covenants, or that the proportion of debt position in the company's capital structure is affecting their performance to enhance market value. The high-interest rates of borrowing for investment could have also reflected in the companies' performance. The study further revealed that though earnings persistence affects firm performance the level of impact is very insignificant.

\section{Post estimation tests}

Normality test: Jarque-Bera test to assess the normality in the error terms (residuals) of the models. The results as presented in Table 4 show indication no sign of normality. Nevertheless, this does not represent much of a problem since we are dealing with a sufficiently large sample of data (Figure 1B) [45].

Table 4: Normality test. Source: Author's computation, underlying data from annual reports of firms listed on NSE.

\begin{tabular}{ccc}
\hline Regression & Models & Jarque-Bera normality test \\
\hline TQ and EPERS & I & $4096.000(0.000)$ \\
\cline { 2 - 3 } & II & $8884.000(0.000)$ \\
\hline
\end{tabular}

The figures in brackets are probability values and $\mathrm{Chi}^{2}$ are outside the bracket.

MSP: Market share price; BV: Book value; TQ: Tobin's Q and EQI: Earnings quality indicator

\section{Earnings Persistence}

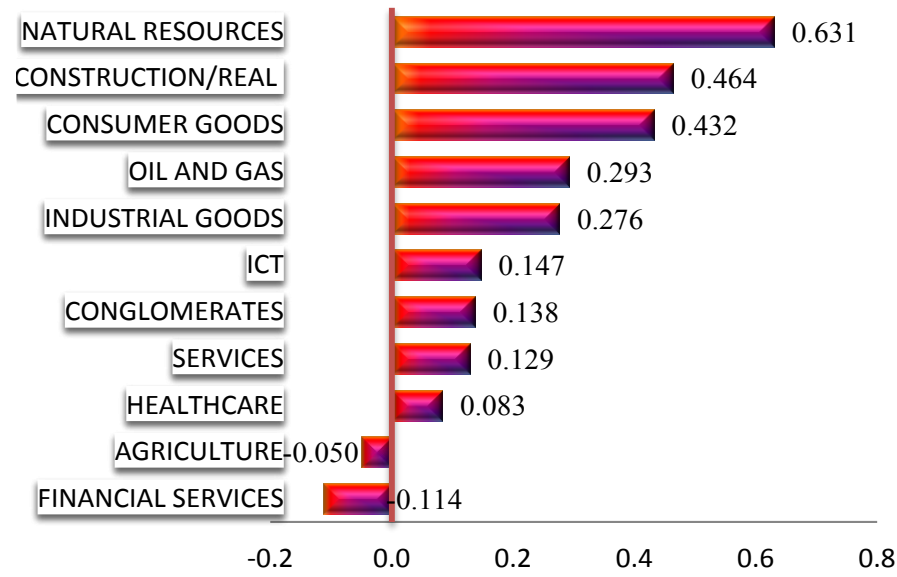

Figure 1B: Earnings persistence according to sectors. Source: Authors' computation, 2018.
Heteroskdascity test: This study used Breusch-Pagan/CookWesberg test to assess the variance in the error terms (residuals) of the models, and the results as indicated in Table 5 revealed that all the models do not suffer from heteroskedasticity. Notwithstanding, panel robust standard error was employed to control the heteroscedasticity.

Table 5: Heteroskedasticity tests. Source: Author's Computation, underlying data from annual reports of firms listed on NSE.

\begin{tabular}{ccc} 
Regressions & Model & Breusch-Pagan test for heteroscedasticity \\
\hline TQ and EPERS & I & $84.140(0.000)$ \\
\cline { 2 - 3 } & II & $50.790(0.000)$
\end{tabular}

The figures in brackets are probability values and $\mathrm{Chi}^{2}$ are outside the bracket.

TQ: Tobin's Q and EPERS: Earnings persistence indicator

\section{CONCLUSION}

From the data analysis carried out, the study was able to establish that earning persistence impacted on firm performance from the perspective of the analysts' point of view. Contrary to our expectation, the study found that earnings persistence exhibited a negative and no significant impact on the firm performance, reducing the predictive ability of future earnings of firms and the financial performance of the listed companies in Nigeria and market share prices. The growth trend of earnings persistence was equally analyzed but revealed a weak growth trend.

\section{RECOMMENDATIONS AND CONTRIBUTION TO KNOWLEDGE}

The leverage proportion of the capital structure profile of Nigerian companies needs to be re-examined as the companies appeared to be highly geared judging from the study result. Leverage indexes policies also need to be revisited by government regulatory agencies for better friendly borrowing conditions from the financial institutions. Furthermore, the analysts should pay more attention to the earnings consistency trend of the sampled companies in order to have an accurate evaluation of reported earnings for a more reliable predictive guide for investors and other stakeholders. The persistency of reported earnings in the Nigerian listed companies must be critically considered by the analysts in making prediction and forecasting, without which, predictions made from them could have negative and misleading implications.

This study extends empirically, the frontier of the emerging market on earnings persistence and firm performance in Accounting in Nigeria. The study made empirical and theoretical contributions to the body literature by providing further evidence on the impact of earnings persistence on firm performance and that sustainability and persistence of earnings are important for future investment projections by analysts and investors. From the study, managers should understand the dynamics of the controlling variables of firm size, leverage plans, to enhance firm performance and other expected operational results.

\section{Suggestion for further studies}

This paper used only earnings persistence as one of the attributes of earnings quality. It would be interesting if further studies are carried out using earnings quality and its full known seven attributes: accounting-based earnings quality attributes (accruals 
quality, earnings persistence, earnings predictability and earning smoothness) and market-based earnings quality attributes (value relevance, earnings timeliness, and earnings conservatism) to investigate their effects on firm performance.

\section{REFERENCES}

1. Armstrong SC, Core JE, Taylor DJ, Verrecchi RE. When does information asymmetry affect the cost of capital? Journal of Accounting Research. 2011;49:1-40.

2. Nelson MW, Skinner DJ. How should we think about earnings quality? A discussion of earnings quality: Evidence from the field. Journal of Accounting and Economics. 2013;56:34-41.

3. Sayari S, Omri A, Finet A, Faycal M. The impact of earnings management on stock returns: The case of Tunisian firms. Global Journal of Management and Business Research. 2013;13:10.

4. Algharaballi E. Earnings management practices and subsequent firm performance of companies listing on the Kuwait Stock Exchange (KSE). University of Southern Queensland. 2013.

5. Aguguom TA, Salawu RO. Earnings quality and firms' book value: An empirical evidence from the listed firms in Nigeria. Journal of Internet Banking and Commerce. 2018;23:1-22.

6. Liu L. The Influence of CSRSCPAs and the quality of financial statements. Asian Journal of Finance \& Accounting. 2018;1:125-135.

7. Pimenel RC, Aguiar AB. The role of earnings persistence in valuation accuracy and the time horizon. Revista de Administracao de Empresas. 2016;56:71-86.

8. Babajani J, Azimi YM. The reliability effect of accruals on stock returns. Journal of Research in Financial Accounting. 2012;4:83-100.

9. Bonna AK. The impact of corporate governance on corporate financial performance. Dissertation Abstracts International: Section A. Humanities and Social Sciences, 2011;72.

10. Salehi M, Vaghfi H, Rajabzadeh AA. The quality impact of optional obligations on stock risk. Research on Accounting and Auditing. 2014;20:72-89.

11. Schipper K, Vincent L. Earnings quality. Accounting Horizons. 2003;17:97-110.

12. Dechow PW, Schrand C. Earnings quality. The Research Foundation of CFA Institute. 2004

13. Oei R, Ramsay A, Mather P. Earnings persistence, accruals and management share ownership. Accounting and Finance. 2008;48:475502.

14. Prapaporn K. The Effect of Accounting-based earnings Attributes on CEO Compensation, (Doctoral thesis), Department of Accounting, Oklahoma State University. 2008.

15. Dechow PM, Dichev ID () The quality of accruals and earnings: The role of accruals estimation errors. The Accounting Review. 2002;77:35-59.

16. Dechow P, Ge W, Schrand C. Understanding earnings quality: A review of the proxies, their determinants and their consequences. Journal of Accounting and Economics. 2010;50:344-401.

17. Islam MA. An analysis of the financial performance of National Bank Limited using financial ratio. Journal of Behavioral Economics, Finance, Entrepreneurship, Accounting and Transport. 2014;2:121. 129.

18. Hifza M. Determinants of insurance companies' profitability: An analysis of insurance sector of Pakistan. Academic Research International. 2011;3:234-341.
19. Alnodell AA. The Impact of IFRS adoption on the value relevance of accounting information: Evidence from the Insurance sector. International Journal of Business and Management. 2018;13:4-12.

20. Siddiqi MN. Recent theories of profit, (1stedn), Aligarh, Aligarh Muslim University Press. 1971.

21. Myers J, Myers L, Omer T. Exploring the term of the auditor-client relationship and the quality of earnings: A case for mandatory auditor rotation? Accounting Review. 2003;78:779-799.

22. Sabrin V, Sarita B, Takdir D, Sujono. The effects of profitability on firm size in manufacturing companies at Indonesia stock exchange. The International Journal of Engineering and Science. 2016;5:81-89.

23. Tayebe J, Jamal B, Hamid RM. Investigating the effect of firm size and financial leverage on the relationship between cost management and relevance of accounting information. The Caspian Sea Journal. 2016;10:335-342.

24. Sucuahi W, Cambarihan JM. Influence of profitability to the firm value of diversified companies in the Philippines. Accounting and Finance Research. 2016;5:2.

25. Wolfer J, Sauaia AC. The Tobin's Q as a company performance indicator, developments in business and simulation and experience learning. Accounting Journal. 2003;30:1.

26. Gaio C, Raposo C. Earnings quality and firm valuation: International evidence. Accounting and Finance. 2011;51:467-499.

27. Ficici A, Aybar BC. Corporate governance and firm value in emerging markets and empirical analysis of ADR issuing emerging market firms. Emerging Markets Journal. 2012;2:38-51.

28. Hoyt RE, Liebenberg AP. The value of enterprise risk management: Evidence from the U.S. insurance industry. Journal of Risk \& Insurance. 2011;78:795-822.

29. Peasnell KV, Pope PF, Young S. Board monitoring and earnings management: Do outside directors' influence abnormal accruals? Journal of Business Finance and Accounting. 2005;32:1311-1346.

30. Hamidzadeh S, Zeinali M. The asset structure and liquidity effect on financial reporting quality at listed companies in Tehran stock exchange. Arabian Journal of Business Management and Review. 2015;4:121-127.

31. Singh M, Davidson WN. Agency costs, ownership structure and corporate governance mechanisms. Journal of Banking and Finance. 2003;27:793-816

32. Hribar P, Nichols CD. The use of unsigned earnings quality measures in tests of earnings management. Journal of Accounting Research. 2007;45:1017-1053.

33. Ali U, Noor AM, Khurshid MK, Mahmood A. Impact of firm size on earnings management: A study of textile sector of Pakistan. European Journal of Business and Management. 2015;7:108-187.

34. Robert GM, Jan, GM. The moderating effect of firm size on the relationship between capital structure and financial distress of nonfinancial companies in Kenya. Journal of Accounting. 2017;5:151-158.

35. Frank MZ, Goyal VK. Capital structure decisions: Which factors are reliably important? Financial Management Association International. 2010;38:1-37.

36. Acheampong P, Agalega E, Kwabena AS. The effect of financial leverage and market size on stock returns on the Ghana Stock Exchange: Evidence from selected stocks in the manufacturing sector. International Journal of Financial Research. 2014;5:125-134.

37. Graham RC, King RD. Accounting practices and market valuation of accounting numbers. Evidence from Indonesia, Korea, Malaysia, the Philippines, Taiwan and Thailand. The International Journal of Accounting. 2000;35:445-470. 
38. Green RC, Hollifield B. The personal-tax advantages of equity. Journal of Financial Economics. 2003;67:175-216.

39. Kemsley D, Nissim D. Valuation of the debt tax shield. The Journal of Finance. 2002;57:2045-2073.

40. Taggart RA. Secular patterns in the financing of U.S. corporations. In: Friedman BF (Ed.) corporate capital structures in the United States, University of Chicago Press. 1985.

41. Ghosh A, Clayton R. Debt and equity market reaction to employment report. Review of Pacific Basin Financial Markets and Policies. 2006;9:431-440.
42. Jensen MC. Eclipse of the public corporation. Harvard Business Review. 2006;5:61-74.

43. Luo Q, Hachiya T. Corporate governance, cash holdings, and firm value: Evidence from Japan. Review of Pacific Basin Financial Markets and Policies. 2005; 8:613-636.

44. Li CA, Ma HC. The performance and cash flows of newly raised funds. Review of Pacific Basin Financial Markets and Policies. 2010;13:539. 557.

45. Oscar T. Linear regression using strata, Data and statistical services, Princeton University. 2007. 